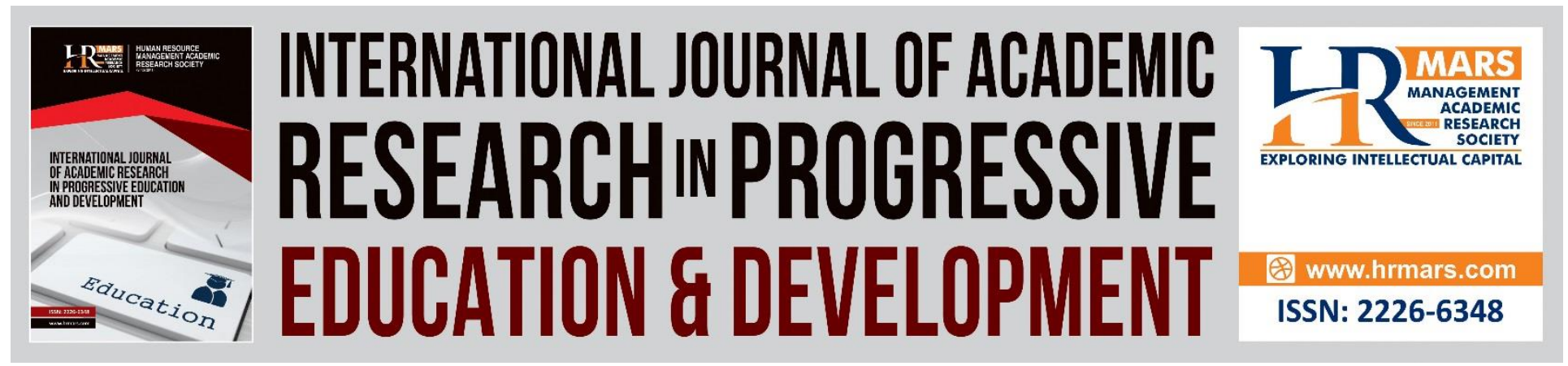

\title{
Teaching and Learning by Using Online Application during Movement Control Order
}

Nor Haliza Che Hashim, Kamisah Osman

To Link this Article: http://dx.doi.org/10.6007/IJARPED/v10-i2/10143

DOI:10.6007/IJARPED/v10-i2/10143

Received: 14 April 2021, Revised: 16 May 2021, Accepted: 30 May 2021

Published Online: 12 June 2021

In-Text Citation: (Hashim, \& Osman, 2021)

To Cite this Article: Hashim, N. H. C., \& Osman, K. (2021). Teaching and Learning by Using Online Application during Movement Control Order. International Journal of Academic Research in Business and Social Sciences, 10(2), 605-614.

Copyright: (C) 2021 The Author(s)

Published by Human Resource Management Academic Research Society (www.hrmars.com)

This article is published under the Creative Commons Attribution (CC BY 4.0) license. Anyone may reproduce, distribute, translate and create derivative works of this article (for both commercial and non-commercial purposes), subject to full attribution to the original publication and authors. The full terms of this license may be seen at: http://creativecommons.org/licences/by/4.0/legalcode

Vol. 10(2) 2021, Pg. 605 - 614

http://hrmars.com/index.php/pages/detail/IJARPED

JOURNAL HOMEPAGE

Full Terms \& Conditions of access and use can be found at http://hrmars.com/index.php/pages/detail/publication-ethics 


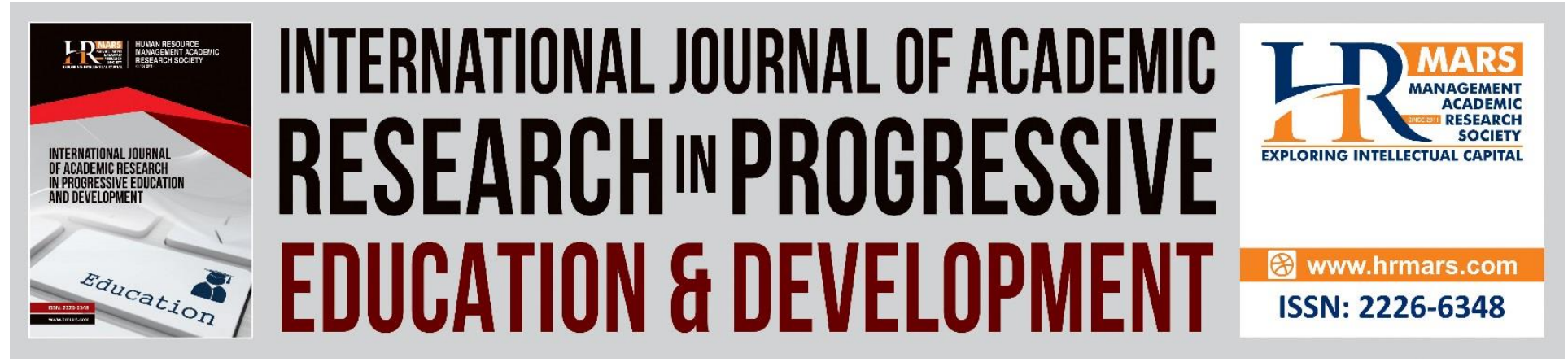

\title{
Teaching and Learning by Using Online Application during Movement Control Order
}

\author{
Nor Haliza Che Hashim, Kamisah Osman \\ Faculty of Education, Universiti Kebangsaan Malaysia, 43600 Bangi, Selangor, Malaysia \\ Email: halyzahashim@gmail.com, kamisah@ukm.edu.my
}

\begin{abstract}
Online teaching and learning have become the new norm in today's educational world. Technology in education allows traditional teaching and learning methods to be improved and simplified. In this modern era, educators, specifically teachers and lecturers, take on the role of facilitators. Instead of being the main vessel of knowledge, they are responsible for assisting and support students' learning process. The existence of various online applications has greatly helped teachers prepare, distribute, and evaluate students' assignments. This study was conducted to identify the use of online applications in the teaching and learning process during the Movement Control Order, which has been implemented in Malaysia implemented to prevent the spread of the COVID-19 outbreak since March 18, 2020. The Movement Control Order has led to the closure of educational institutions, including schools and universities. Consequently, educators have been using online applications to deliver their teaching contents to continue the teaching and learning process and finish the syllabus. This study was conducted to determine digital learning status at Tunku Abdul Rahman Putra Form Six College, Sabak Bernam, during the Movement Control Order period. The study questionnaire consists of 12 items pertaining to the use of online applications for teaching and learning using during the Movement Control Order. The findings show that all 83 teachers in Tunku Abdul Rahman Putra Form Six College have been teaching online using various applications such as Whatsapp (89.20\%), Telegram (71.10\%), and Google Classroom (48.20\%). The use of chat group in online applications makes it easier for teachers to communicate with the students and allows teachers to monitor students' readiness to study and their progress. This limitless technology enables the teaching and learning process to occur at any time without having to be in a classroom. It also helps improve communication skills between teachers and students.
\end{abstract}

Keywords: Movement Control Order, Online Applications, Teaching and Learning

\section{Introduction}

Rapid development in technology facilitates the work process and improves the quantity and quality of productivity, including education in Malaysia. The development of educational 
technology began with personal computers in the 1980s, and now it is known as digital learning or e-learning.

The use of technology in education or, more precisely 'educational technology' has now been widely practice at all levels of education, both in schools and higher learning institutions. Educators begin to emphasize the use of technology in the teaching and learning process, in line with the recommendation of the Ministry of Education through the Malaysian Education Development Plan (PPPM) 2013 - 2025 that leverages Information and Communication Technology (ICT) to improve the quality of learning and transform educational capabilities and qualities in Malaysia. European scientists and scholars, such as Finn (1960), Galbraith (1967) and Seattler (1990), defined technology as an approach or technique which uses scientific knowledge to solve a problem. Technology is also a product or material derived from the process of the technology itself, such as hardware or software. Any form of software, whether online or offline, is considered a current technology. On the other hand, online applications are software that can be accessed through an internet connection using technology tools such as computers, tablets, or smartphones.

Such borderless technology is especially significant to continue teaching and learning activities during the COVID-19 pandemic that has completely paralyzed the education system due to the closure of schools, colleges, and universities. COVID-19 or Corona Virus Disease 2019 pandemic has paralyzed, including administration, economic, and social systems globally. The virus originated from bats and snakes consumed as exotic meat and was discovered in Wuhan, China, in 2019. It can be transmitted from person to person through close contact with infected individuals (Ministry of Health Malaysia, 2020). The first cases of the novel virus in Malaysia was reported on January 25, 2020, when several tourists from the Republic of China were admitted to Sungai Buloh Hospital, Selangor. Since early 2020, COVID-19 has continued to haunt the world, and it has now severely affected nearly every major world power, including the United States, Italy, Germany, Japan, France, and Singapore. Like other countries, the Movement Control Orders have been implemented in Malaysia to curb this dangerous virus. Following the recommendation from the Ministry of Health Malaysia (MOH), the Prime Minister of Malaysia, Tan Sri Muhyiddin Yassin, in his speech on March 16, 2020, has announced that the Movement Control Order (MCO) would be enforced throughout Malaysia from March 18, 2020, to March 31, 2020. Subsequently, the MCO implementation continued until May 3, 2020, before moving to the Conditional Movement Control Order (CMCO) between May 4, 2020, and June 9, 2020. The MCO and CMCO are the first of their kind implemented in Malaysia since Independence Day in 1957.

The Movement Control Order (MCO) and the Conditional Movement Control Order (CMCO) are initiatives taken to restrict social contacts within the community to control the spread of COVID-19 infection. The MCO forced all government and private premises, except those involved in essential services, such as retail and food supply, to close. Furthermore, any religious, social and sports gathering are not permitted during the MCO and CMCO periods. During this time, Malaysians were prohibited from leaving the country, and foreign tourists were barred from entering Malaysia. The MCO and the CMCO implemented by the government are 
included under the Prevention and Control of Infectious Diseases Act 1988 (Act 342) to control the spread of infectious diseases (National Security Council, 2020).

Due to the risk of COVID-19, it is crucial to replace face-to-face classes and laboratory studies with online classes. Malaysian schools need to continue identifying the best methods to resume teaching and learning while protecting their teachers and students from the COVID-19 virus. Online education became a pedagogical shift from traditional method to the modern approach of teaching and learning. Previously, e-learning and distance education were popularly considered as the part of non-formal education, but as of now, it seems that it would gradually replace the formal education system if the circumstances enduringly persist over the time. Some of the most popular online communication platforms that would change the destination and direction of the whole education system across the world in post-COVID-19 circumstances are Google Meet, Zoom, and Google Classroom.

The closure of all educational institutions during the MCO and CMCO sparked a phenomenon among educators, highlighting the use of technology in teaching and learning. Educators serve as planners, managers, and evaluators in teaching and learning. Therefore, even if the educational institution is directed to shut down, all educators can still plan and implement their teaching effectiveness through online learning. The implementation of this online learning enables students to develop lifelong learning skills. Students need to find materials that teachers or lecturers have provided in virtual learning platforms such as Google Classroom or e-learning. Students need to manage time properly so that assignments given by teachers or lecturers can be completed promptly. Besides, students also have to make various decisions that require problem-solving skills such as unstable or weak internet problems, classmates or a group member without internet access, laptop problems, and so on. Online learning enables students to become independent and no longer rely on teachers solely as a source of knowledge.

\section{Literature Review}

Technology in education can greatly benefit teaching and learning as listed by the Curriculum Development Division (2014), enabling students to gather information quickly, provide opportunities for students to learn effectively with minimal guidance, and enhance student creativity. Technology in education focuses on the technological tools and media that assist in the communication of knowledge between teachers and students.

According to Hajar et al (2011), the adoption of technology in education is divided into two parts: equipment and the learning process itself. In terms of equipment, it is said to be prepared while learning. It is the whole method of delivery. The study by Aziah and Taufik (2016) found that e-learning enabled conventional methods to be online and contributed to very flexible teaching and learning environment. A study conducted by Hazwani, Raudhiah and Norziah (2017) found that e-learning can make the teaching and learning system more flexible as teachers and students can choose when and where to teach and learn because they do not have to attend anywhere at any given time. 
According to Algahtani (2011), there are two modes in online learning, which are synchronous and asynchronous depending on the application of applying optional timing of interaction. The synchronous online learning provides the direct interaction between the teachers and students during class through tools such as video conference or chatrooms. While asynchronous online learning provides the opportunity for the teachers and students to interact before or after the online class through thread discussion and emails. The online learning provides advantages in independent learning and developing new skills in the process leading to life-long learning (Dhawan, 2020).

Moreover, according to Zaki et al. (2014), online applications provide various functions that facilitate the teaching and learning process compared to traditional methods that can only provide certain functions with very limited time and cost. On the other hand, Norliza, Sattar, and Roseamnah (2013) found that using online applications facilitates learning and allows teachers to provide teaching materials and supervise students' learning activities.

Hence, online teaching mode is providing the feeling of psychological safety to learning community in COVID-19 afflicting period. The pandemic has had a significant impact on the education landscape of the country, accelerating the digitalization of form six education. Remote learning has become the new norm, with new, more flexible teaching and learning processes to ensure that meaningful learning is achieved in the best possible way. The COVID-19 pandemic situation has posed unprecedented challenges requiring teachers to adapt to teaching online and requires not only knowledge and skills but also confidence regarding success in online teaching (König, Jäger-Biela \& Glutsch, 2020).

\section{Research Methodology}

This study was conducted via Google Form to determine digital learning status for schools in the Sabak Bernam district during the MCO and CMCO period. This study was conducted at a form six college in Sabak Bernam district, Selangor. The study involved all the teaching staff at Tunku Abdul Rahman Putra Form Six College (KiSTARP), Sabak Bernam.

This study used a questionnaire prepared by the Academic Division of Selangor State Education Department (JPN) for reporting purposes using virtual teaching and learning methods or e-learning throughout the MCO and CMCO period. This survey has 12 items covering digital learning throughout the $\mathrm{MCO}$ and $\mathrm{CMCO}$ through the available online applications platform.

\section{Results and Discussion}

Descriptive analysis was performed to obtain the percentage of teachers' consent for the most frequently online applications used in teaching and learning processes during the MCO and CMCO period. The findings show that all 83 teachers in Tunku Abdul Rahman Putra Form Six College participated in this study. Table 1 shows the number of teachers according to the subjects offered at Tunku Abdul Rahman Putra Form Six College. 
Vol. 10, No. 2, 2021, E-ISSN: 2226-6348 @ 2021 HRMARS

Meanwhile Figure 1 shows the types of online applications used by teachers in teaching and learning during the period of movement control orders. The findings show that the most frequently used online application in teaching and learning during the MCO period was the Whatsapp (89.20\%), followed by the Telegram (71.10\%), and the Google Classroom (48.20\%). Online applications such as Whatsapp, Telegram, and Google Classroom are accessible through various mobile technology tools such as laptops, tablets, and smartphones that are necessary for every generation today. Besides, these three applications make it easier for teachers to send out assignments, reminders and progress reports to their students. Technology in education has enabled learning activities such as browsing the web, running programs and sharing notes between individuals, available anywhere and anytime.

\section{Table 1}

Number of Teachers Implementing Online Teaching during the Period of Movement Control Orders

\begin{tabular}{ll}
\hline Subject & Number \\
& Teachers \\
\hline General Studies & 16 \\
Bahasa Melayu & 9 \\
Communicative Malay Literature & 4 \\
History & 5 \\
Geography & 5 \\
Visual Arts & 4 \\
Sports Science & 3 \\
Economy & 3 \\
Bussiness Studies & 3 \\
Syari'ah & 1 \\
Mathematics (M) & 1 \\
Chemistry & 2 \\
Physics & 2 \\
Biology & 2 \\
Mathematics (T) & 4 \\
ICT & 2 \\
MUET & 14 \\
Counseling & 3 \\
\hline Total & 83 \\
\hline
\end{tabular}

\section{Figure 1}

Types of Online Applications Used by Teachers in Teaching and Learning during the Period of Movement Control Orders 
Vol. 10, No. 2, 2021, E-ISSN: 2226-6348 @ 2021 HRMARS

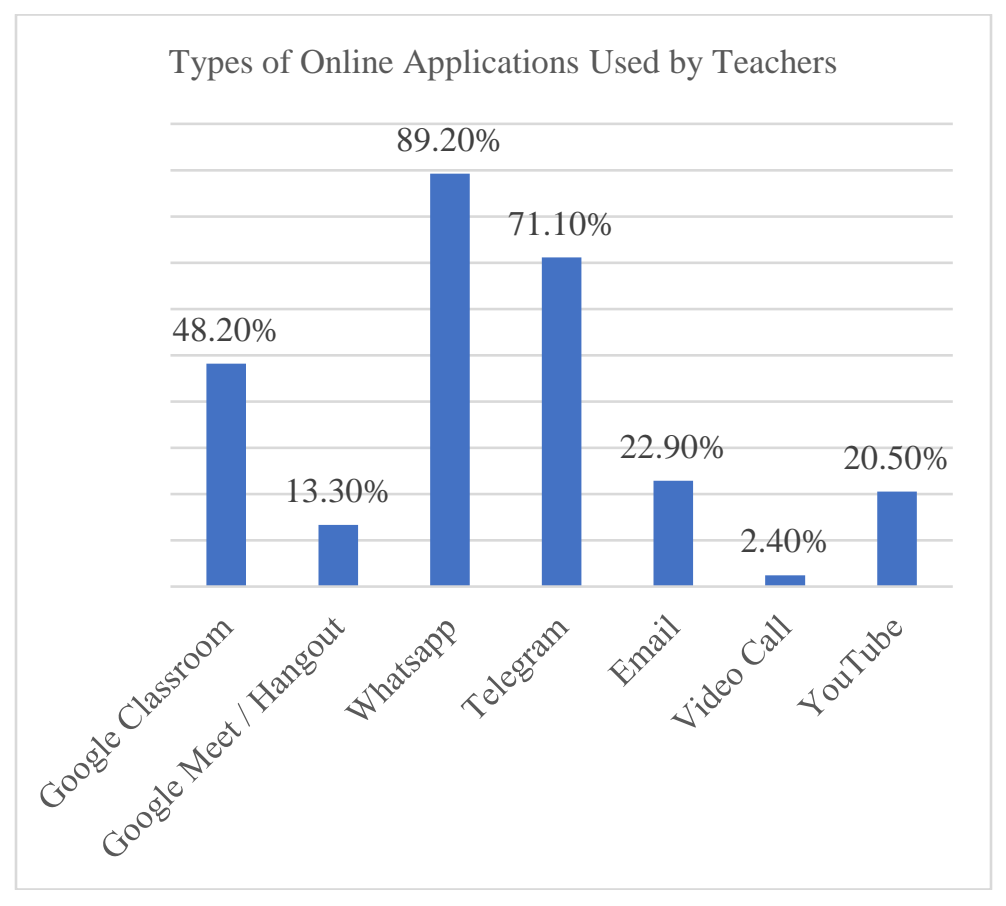

\section{WhatsApp}

WhatsApp Messenger or simply WhatsApp, is an American freeware that allows users to send text messages and voice messages, make voice call and video call, and share images, documents and user locations. The Whatsapp application provides a very different communication platform than the previous Short Message System (SMS) application. The advantage of the Whatsapp application is its simple system, low cost, easy to download, and delivery of messages quickly and easily (Church and De Oliveira, 2013).

Bouhnik, Deshen, and Gan (2014), in an article entitled "Whatsapp Goes to School: Mobile Instant Messaging between Teachers and Students", stated that Whatsapp groups created between teachers and students are useful for four things: creating two-way communication between teachers and students, fostering a comfortable atmosphere for socializing, encouraging conversations and sharing of learning materials with students, and as a learning platform that is easier and closer to students.

\section{Telegram}

Telegram applications are another medium of interaction that is quite popular among teenagers today. Telegram is a freeware, multi-platform messaging service founded by Russian entrepreneur. The application has the advantage of sending any file such as pictures or videos, large but still quality. Additionally, another advantage is that Group Chat on Telegram can accommodate up to 1000 members.

A study by Aghajani and Adloo (2018) stated that students have a positive attitude towards cooperative learning through the use of Telegram applications. Studies using this 
experimental design have compared conventional methods with Telegram methods to foster cooperative attitudes and improve students' writing skills.

\section{Google Classroom}

Google Classroom is a free, user-friendly education application provided by Google. This application can be utilized for a learning environment in conjunction with 21st Century Learning. Google Classroom integrates Docs, Sheets, Slides, Gmail and Calendar into a cohesive platform to manage the communication between teachers and students.

A study conducted by Rana and Mostafa (2018) shows that two main criteria of Google Classroom are ease of use and positive response among students. These criteria have influenced teaching and learning by increasing the understanding towards the application's importance to educators and students. This is supported by another study by Keith R Heggart and Joanne Yoo (2018). They stated that the Google Classroom application had increased student participation in learning and improved classroom dynamics. The data in this study were analyzed to assess the use of online application facilities, especially Google Classroom and teacher pedagogical practices.

\section{Conclusion}

In these changing times, students are more driven towards using a mobile phone for every purpose. The world is at the fingertips and students can get access to any information from anywhere. A mobile phone hence can be used for a number of such purposes. What makes the information easily available is mobile applications. Every mobile app has a unique feature which offers its own set of services. Due to the mobile phones and the various feature-oriented applications, students can learn at their pace and take their time at understanding things, as everything is just a click away.

Hence it is crucial for teachers in Tunku Abdul Rahman Putra Form Six College to start experimenting and experiencing online teaching or the form six education system will be left far behind. Online learning enables teachers in Tunku Abdul Rahman Putra Form Six College to embrace the real world application of theory through multimedia, video, chat, and interactivity. For teachers in Tunku Abdul Rahman Putra Form Six College, teaching by using online applications open up new possibilities to stimulate young minds. Teachers can effectively harness the power of technology to bring educational theories into the virtual classroom. The practical benefits to teachers can be measured in terms of time-based efforts and workload reduction. This study was an attempt to provide insights into teachers' skills of the newly implemented online learning across the schools in Malaysia. Knowing the benefits of online learning alone will not help accelerate the adoption process if teachers lack sufficient pedagogical and technological knowledge and skills. As such, technology innovations in schools must be accompanied with reliable and effective ongoing support by providing what teachers need. 


\section{Acknowledgement}

First and foremost, I would like to say thank you to all the science students and also the teachers in Tunku Abdul Rahman Putra Form Six College (KiSTARP) for giving me full cooperation and helping me to conduct this research. I also would like to say thank you to District Education Office (PPD) Sabak Bernam, and also Selangor State Education Department (JPN) for always encouraging teachers to become researchers in their classroom by Research and Development (R\&D) programs. Last, but not the least, I would like to express my sincere gratitude to my supervisor, Prof. Dr. Kamisah binti Osman. This paper and the research behind it would not have been possible without the exceptional support of my supervisor.

\section{References}

Abdul Aziz, N. A., \& Ahmed, M. T. (2016). E-pembelajaran dalam pengajaran dan pembelajaran Bahasa Melayu di IPG kampus Ipoh. Jurnal Penyelidikan Dedikasi. Jilid 11, 116 - 130

Aghajani, M., \& Adloo, M. (2018). The effect of online cooperative learning on students' writing skills and attitudes through telegram application. International Journal of Instruction. 11(3), $433-448$.

Algahtani, A. F. (2011). Evaluating the effectiveness of the e-learning experience in some universities in Saudi Arabia from male students' perceptions. Durham theses, Durham University, UK.

Al-Maroof, R. S., \& dan Al-Emran, M. (2018). Students acceptance of Google Classroom: An exploratory study using PLS-SEM approach. International Journal of Emerging Technologies in Learning (iJET). 13 (06), $112-123$.

Amiruddin, A. Z., Hassan, A. T., Abdul Rahman, A., Abdul Rahman, N., \& Abu Bakar, M. S. (2014). Penggunaan aplikasi atas talian dalam proses pengajaran dan pembelajaran bahasa ketiga: Pengenalan kepada Quizlet.com. Prosiding Seminar Antarabangsa Kelestarian Insan, 1 - 16

Bouhnik, D., Deshen, M., \& Gan, R. (2014). Whatsapp goes to school: Mobile instant messaging between teachers and students. Journal of Information Technology Education Research 13(1), 217-231.

Church, K., \& De Oliveira, R. (2013). What's up with Whatsapp? Comparing mobile instant messaging behaviours with traditional SMS. Proceedings of the $15^{\text {th }}$ International Conference on Human-Computer Interaction with Mobile Devices and Services, 352 - 361.

Dhawan, S. (2020). Online learning: a panacea in the time of COVID-19 crisis. Journal of Educational Technology Systems 0(0), 1-18.

Finn, J. D. (1960). Technology and the Instructional Process, Audiovisual and Communication Review 8 (1). New York: Springer

Galbraith, J. (1967). The New Industrial State. Boston: Houghton Mifflin.

Halili, S. H., Sulaiman, S., \& Abd. Rashid, M. R. (2011). Keberkesanan proses pembelajaran menggunakan teknologi sidang video. Jurnal Pendidikan Malaysia. 36

Heggart, K. R., \& Yoo, J. (2018). Getting the most from Google Classroom: A pedagogical framework for tertiary educators. Australian Journal of Teacher Education. 43(3). 9. 140 153. 
Hussin, N., Rasul, M. S., \& Abd. Rauf, R. (2013). Penggunaan laman web sebagai transformasi dalam pengajaran dan pembelajaran Pendidikan Islam. The Online Journal of Islamic Education. Vol. 1 (2), $58-73$

König, J., Jäger-Biela, D. J., \& Glutsch, N. (2020). Adapting to online teaching during COVID-19 school closure: teacher education and teacher competence effects among early career teachers in Germany. European Journal of Teacher Education 43(4), 608-622

Najib, M. H., Abu Bakar, N. R., \& Othman, N. (2017). E-pembelajaran dalam kalangan pelajar di sebuah institusi pengajian tinggi di Selangor. Attarbawiy: Malaysian Online Journal of Education 1(1), $74-82$

Saettler, P. (1990). The Evolution of American Educational Technology. Eaglewood, Colorado: Libraries Unlimited 